\title{
Reflective function and identity in adolescents with clinical and nonclinical symptoms
}

\author{
Função reflexiva e identidade em adolescentes com sintomas clínicos \\ e não clínicos
}

Luciane Maria Both, ${ }^{1}$ (D) Sílvia Pereira da Cruz Benetti, ${ }^{1}$ Geoff Goodman ${ }^{2}$

\begin{abstract}
Introduction: Reflective function is developed in the context of secure attachment and corresponds to the ability to understand one's mental states and those of others. Thus, identity develops, which relates to the experience of self as unique, continuous and coherent.

Objective: To identify reflective function and identity features in adolescents with clinical and nonclinical symptoms of mental health problems.

Method: Participants were 188 Brazilian high school students aged $14-17$ years: $30.3 \%$ with clinical symptoms and $69.9 \%$ with nonclinical symptoms.

Results: Adolescents with clinical symptoms showed lower levels of reflective function and greater disintegration of identity. Conclusion: Adolescence is a vulnerable time for mental health problems associated with reflective function and identity. Early identification of symptoms is a matter that needs attention to prevent future consequences.

Keywords: Reflective function, mentalizing, identity, adolescence.
\end{abstract}

Resumo

Introdução: A função reflexiva é desenvolvida no contexto do apego seguro e corresponde à capacidade de compreender os seus próprios estados mentais e os dos outros. Assim, desenvolve-se a identidade, que se relaciona com a experiência do eu como única, contínua e coerente.

Objetivo: Identificar função reflexiva e características identitárias em adolescentes com sintomas clínicos e não clínicos de problemas de saúde mental.

Médoto: Os participantes foram 188 estudantes do ensino médio com idade de 14 a 17 anos: 30,3\% com sintomas clínicos e $69,9 \%$ com sintomas não clínicos.

Resultados: Adolescentes com sintomas clínicos apresentaram menores níveis de função reflexiva e maior desintegração da identidade.

Conclusão: A adolescência é um momento vulnerável para problemas de saúde mental associados à função reflexiva e identidade. A identificação precoce dos sintomas é uma questão que precisa de atenção para evitar consequências futuras.

Descritores: Função reflexiva, mentalização, identidade, adolescência.

\footnotetext{
${ }^{1}$ Universidade do Vale do Rio dos Sinos (UNISINOS), São Leopoldo, RS, Brazil. ${ }^{2}$ Clinical Psychology Doctoral Program, Long Island University, Brooklyn, NY, USA. 


\section{Introduction}

Adolescence is a vulnerable period for the onset of mental health problems. ${ }^{1}$ According to the United Nations, children and adolescents account for about 14.2 to $30 \%$ of the world population, with indications of high rates of prevalence of mental disorders in these age groups. ${ }^{2}$ The Brazilian national prevalence of mental health problems in children and adolescents ranges from 7 to $12.7 \% .^{3}$ Estimates indicate that one in every four to five children and adolescents have a mental disorder. ${ }^{4}$ It is also estimated that 10 to $25 \%$ of children and adolescents eventually show clinical symptoms. ${ }^{5}$

In addition to the clinical manifestations and risk factors related to the manifestations of psychopathology, the important intrapsychic changes taking place in affective and cognitive dimensions during adolescence are fundamental elements to understanding mental health problems. Acquisitions related to the expansion of the adolescent's reflective function and the development of a sense of autonomous self, associated with the construction of a personal identity, are key points towards mental health. In the opposite direction, difficulties in reflective function and diffusion of identity are common features in personality disorders diagnosed in adults, ${ }^{6,7}$ in patients with depression, ${ }^{8}$ schizophrenia, ${ }^{9}$ autism spectrum disorders, ${ }^{10}$ psychopathy, ${ }^{11}$ anxiety, ${ }^{12}$ eating disorders ${ }^{13}$ and in victims of frequent traumas. ${ }^{14,15}$

Children and adolescents who experienced traumatic situations throughout their development, such as abuse and violence or accidental traumatic events, may have important psychological after-effects that could culminate in the establishment of disorganized and unstable psychic structures in adulthood: low reflective function and diffuse identity. This disorganized psychological functioning is characterized by split-off object representations, unstable experiences, constant difficulty in maintaining continuous and rewarding relationships with others, and significant shortcomings in organizing a sense of identity. ${ }^{7,16}$ During adolescence, one of the central points of psychological development is the acquisition of identity, and a secure attachment makes it easier for adolescents to assimilate the changes experienced. ${ }^{17}$ Developing reflective function is also considered a protective factor. ${ }^{18}$

Even though the association between reflective function and psychopathology is recognized, there is still a need to deepen the knowledge and better understand how these aspects are manifested in different characteristics, both in clinical subjects and in healthy individuals, especially during adolescence. Thus, this study focuses on the development of reflective function and identity in adolescents with clinical and nonclinical symptoms. ${ }^{19-21}$

\section{Adolescence: reflective function and identity}

Adolescence is a time of resignifying identity, ${ }^{22}$ which is characterized by intense physical, psychological and social changes, ${ }^{23-25}$ and greater requirements and responsibilities that society demands of the individual given his or her new status. ${ }^{26}$ Transformations can mean losing social references ${ }^{27}$ and a symbolic reordering of the child's representational systems, ${ }^{28,29}$ in which the new representational scheme is anchored in early relational experiences. ${ }^{23}$

Attachment/bonding is a universal human need ${ }^{30,31}$ that depends on the caregiver being sensitive to the child's signals and responding to their comfort and protection needs, ${ }^{32}$ as well as the baby's response. ${ }^{33}$ Please note that environmental conditions, especially in the first year of life, are crucial to the emotional development of individuals ${ }^{34,35}$ and become the basis for emotional and behavioral regulation, as well as a representational model of self, of others, and of interpersonal relationships. ${ }^{31,36,37}$

Therefore, the experiences internalized from the relations with primary objects are the basis for the construction of complex representational structures ${ }^{38}$ and influence "how the child interprets reality and interacts with it" (p. 393). ${ }^{39}$ These mental representations may be valid or distorted. ${ }^{33}$ In this sense, understanding and recognizing mental states is critical and may be compromised. The ability to understand mental states is linked to mentalization. 40

The ability to mentalize - reflective function - started to be discussed especially in more severe cases associated with personality disorders, particularly borderline. ${ }^{14,41-}$ 44 It refers to the process of social construction that gives meaning to the self and to others in terms of subjective mental states and processes, both implicit and explicit. ${ }^{40,45}$ It is vital for the organization of the self, a consequence of secure attachment. ${ }^{15,43,46,47}$ There are problems in the development of mentalization when there is trauma, neglect of primary care, or a history of attachment issues, i.e., when children are exposed or vulnerable. ${ }^{40,45,48}$ The concept of reflexive function refers to the operationalization of mentalization. ${ }^{49}$ However, these two concepts are often interchangeable. ${ }^{45,49}$

In adolescence, mentalization aids in the processing of losses and changes, allowing the interpretation of mental states of their own conduct and that of others, assisting in regulating emotions and impulse control and maintaining the individual's stability and sense of security. ${ }^{18,31,49}$ According to Fonagy \& Target, adolescence is a period that can reveal the flaws established in 
the early years of life, which until then could be hidden. ${ }^{50}$ Another aspect that has been highlighted is the implication of this connection with the process of adolescent identity construction. 7,49

This identity refers to the experience of oneself as unique; there are clear boundaries between self and other, stable self-esteem, accurate self-assessment and capacity for self-regulation. ${ }^{51}$ According to Erikson, identity means the "constancy of itself and continuity through time" ( $p .23$ ), as well as recognizing the other. ${ }^{52}$ To complement that, according to Kernberg et al., the concept of identity is not unique or simple. The authors refer to identity as awareness about oneself as consistent and continuous over time as well as the recognition of others as consistent and continuous beings. They also indicate that identity is made up of different components involving real body image, "subjective sense of being what it is" (p. 32), behavioral cohesion and activities, temporally continuous self, "ability to be genuine and authentic" (p. 32), gender clarity, internalized conscience, and ethnicity. ${ }^{7}$

In evolutionary terms, identification is the basis of the structure of the self. Thus, identity results from an ego process of partial representations of objects, based on a series of representation systems. ${ }^{7}$ Still, identity consists of two aspects: consistency/inconsistency and continuity/discontinuity. ${ }^{53}$ Inconsistency is defined as a difficulty in remembering what was done one day after the other. If there is temporal discontinuity, it is difficult to talk about the story of one's life and a future perspective, and there are often inconsistent or contradictory behaviors. Incoherence refers to incoherent, inconsistent, fragmented feelings. There are feelings of "do not know who you are" and sometimes feeling unreal, with a perception of emptiness. ${ }^{54}$

The diffusion of identity is defined as the lack of integration of self-concept from the patient's subjective experience of chronic emptiness and self-perceptions as well as contradictory behavior. ${ }^{55}$ There is also emotional instability, lack of personal plans, impulsivity, and difficulties in interpersonal relationships. ${ }^{56}$ It is noteworthy that the level of identity integration is not associated with age but with the presence or absence of a personality disorder. ${ }^{57}$

We emphasize the importance of the identification, intervention and prevention in different types of symptomatology, because the assessment and identification of symptoms in adolescence deserve attention to prevent future consequences. ${ }^{11,20,21}$ Overall, the identification of emotional and behavioral problems is important since these problems affect development in other areas of life. ${ }^{58}$ Specific issues of adolescence need to be better understood and disseminated. ${ }^{59}$

\section{Objectives}

The main objective of this study was to identify the characteristics of reflective function and identity in adolescents with clinical and nonclinical symptoms.

\section{Method}

\section{Participants}

A total of 188 adolescents aged 14 to 17 years (mean $[M]=15.8$ ) residing in the Gramado, in the Serra Gaúcha region, in southern Brazil, participated in the investigation. The sample was selected by convenience at a public school. All students from the first two years of high school in the city's public school were invited to participate. They totaled seven classes of about 30 students each. The only inclusion criterion was being enrolled in the municipal school where the study was conducted. Students who did not return a completed parental written informed consent form were excluded.

To determine sample size, we considered the number of adolescents residing in the city where the study was conducted, namely, a total of 4,200 adolescents. ${ }^{60}$ We assumed a sampling error of $5 \%$ and a $95 \%$ confidence level. Thus, our sample would require a minimum of 182 participants.

Of the 188 students selected, 57 (30.3\%) showed clinical symptoms, whereas in 131 the symptoms were nonclinical (69.9\%). In the sample, 124 were girls (66\%), $138(73.4 \%)$ had not failed in school, 121 (64.4\%) lived with their father and 167 (88.8\%) lived with their mother. With regard to the parents' relationship, 125 (66.5\%) were married. Parents' schooling levels varied, as observed in Table 1.

\section{Instruments}

Sociodemographic questionnaire

A questionnaire was prepared by the research group to collect information on schooling levels, family characteristics, and other factors considered relevant for the study.

Table 1 - Parents' schooling levels, n (\%)

\begin{tabular}{lcc}
\hline Level & Father & Mother \\
\hline Illiterate & $4(2.1)$ & $2(1.1)$ \\
Complete primary education & $77(41)$ & $61(32.4)$ \\
Complete high school & $65(34.6)$ & $76(40.4)$ \\
Technical education & $5(2.7)$ & $12(6.4)$ \\
Complete higher education & $23(12.2)$ & $34(18.1)$ \\
The student does not know & $14(7.4)$ & $3(1.6)$ \\
\hline
\end{tabular}


Assessment of Identity Development in Adolescence (AIDA)

This assessment tool of adolescent identity (12-18 years) developed by Goth et al. was based on Kernberg's construct of the polarity between the positions of identity integration and identity diffusion. It consists of 61 items rated using a 5-point Likert scale and is composed of two scales (Table 2). A higher score corresponds to greater identity disintegration. The instrument has shown adequate psychometric properties. ${ }^{61}$ In this study, the instrument showed a total Cronbach's $a=0.93$, and the two scales had a continuous $a=0.69$ and coherence $a=0.93$.

In Brazil, the AIDA questionnaire is being validated by Tardivo et al.; the first author authorized the use of the Portuguese version of the instrument, which was translated by a research group at Universidade de São Paulo (personal communication: Tardivo LC, Malki YM, Barros M, Identity development in Brazil, Congr I'Enfance et de I'Adoles, 2012). The data collected in this study will serve to expand the Brazilian sample.

\section{Reflective Function Questionnaire for Youths (RFQY)}

Developed by $\mathrm{Ha}$ et al., the RFQY is a self-report measure that comprises 46 items scored using a 6-point
Likert scale. ${ }^{62}$ Scale A consists of 23 items in which the ideal reflective function is in the middle of the scale and extreme responses indicate depletion of reflective function. Scale B also has 23 items; here, a higher score indicates higher reflective function. The sum of scales $A$ and $B$ yields a total RFQY score: the higher the score, the greater the reflective function. ${ }^{47}$ In the Englishlanguage validation study of the RFQY, it was found that the higher the frequency of borderline symptoms, the lower the reflective function. The internal consistency of the instrument was 0.71 .62 For the current study, the RFQY presented an $a=0.64$. In personal correspondence with $\mathrm{Ha}$ et al., ${ }^{62}$ we obtained authorization to translate the instrument and develop the Brazilian Portuguese version that is still being validated at Universidade do Vale do Rio dos Sinos (UNISINOS).

\section{Strengths and Difficulties Questionnaire (SDQ)}

Developed by Goodman in the U.S. with the goal of being a short, simple questionnaire to assess the mental health of children and adolescents with a focus on events occurring in the last six months, the SDQ consists of 25 items rated on a 3-point Likert scale, divided into five subscales: emotional symptoms (internal symptoms),

Table 2 - Assessment of Identity Development in Adolescence (AIDA) scales

\begin{tabular}{|c|c|c|}
\hline & $\begin{array}{l}\text { Scale 1: Identity-Continuity vs. Discontinuity } \\
\text { Ego-stability, intuitive-emotional "I" ("changing } \\
\text { while staying the same") }\end{array}$ & $\begin{array}{l}\text { Scale 2: Identity-Coherence vs. Incoherence } \\
\text { Ego-strength, defined "Me" ("non-fragmented } \\
\text { self with clear boundaries") }\end{array}$ \\
\hline $\begin{array}{l}\text { Self-related intrapersonal } \\
\text { Me and I }\end{array}$ & $\begin{array}{l}\text { Sub } 1.1 \text { : Stability in attributes/goals vs. lack } \\
\text { of perspective } \\
\text { - F1: capacity to invest/stabilizing commitment } \\
\text { to interests, talents, perspectives, life goals } \\
\text { - F2: stable inner timeline, historical } \\
\text { biographical self, subjective self sameness, } \\
\text { sense of continuity } \\
\text { - F3: stabilizing moral guidelines and inner } \\
\text { rules }\end{array}$ & $\begin{array}{l}\text { Sub 2.1: Consistent self image vs. } \\
\text { contradictions } \\
\text { - F1: same attributes and behaviors with } \\
\text { different friends or situations, consistent } \\
\text { appearance } \\
\text { - F2: no extreme subjective contradictions/ } \\
\text { diversity of self representations, coherent } \\
\text { self-concept } \\
\text { - F3: awareness of a defined core and inner } \\
\text { substance }\end{array}$ \\
\hline $\begin{array}{l}\text { Social-related interpersonal Me } \\
\text { and You }\end{array}$ & $\begin{array}{l}\text { Sub } 1.2 \text { : Stability in relations/roles vs. lack } \\
\text { of affiliation } \\
\text { - F1: capacity to invest/stabilizing commitment } \\
\text { to lasting relationships } \\
\text { - F2: positive identification with stabilizing roles } \\
\text { (ethnic - cultural - family - self) } \\
\text { - F3: positive body-self }\end{array}$ & $\begin{array}{l}\text { Sub 2.2: Autonomy/ego-strength vs. over- } \\
\text { identification, suggestibility } \\
\text { - F1: assertiveness, ego-strength, no over- } \\
\text { identification or over-matching } \\
\text { - F2: independent intrinsic self-worth, no } \\
\text { suggestibility } \\
\text { - F3: autonomous self (affect) regulation }\end{array}$ \\
\hline $\begin{array}{l}\text { Mental representations, } \\
\text { accessibility and complexity } \\
\text { concerning own and others' } \\
\text { emotions/motives }\end{array}$ & $\begin{array}{l}\text { Sub 1.3: Positive emotional self-reflection } \\
\text { vs. distrust in stability of emotions } \\
\text { - F1: understanding own feelings, good } \\
\text { emotional accessibility } \\
\text { - F2: understanding others' feelings, trust in } \\
\text { stability of others' feelings }\end{array}$ & $\begin{array}{l}\text { Sub 2.3: Positive cognitive self-reflection vs. } \\
\text { superficial, diffuse representations } \\
\text { - F1: understanding motives and behavior, good } \\
\text { cognitive accessibility } \\
\text { - F2: differentiated and coherent mental } \\
\text { representations }\end{array}$ \\
\hline Alfa & $a=0.86$ & $a=0.94$ \\
\hline
\end{tabular}

Integrated identity vs. diffuse identity. ${ }^{61}$ 
conduct problems (external symptoms), hyperactivity/ inattention (external symptoms), relationship problems (internal symptoms) and prosocial behavior (neutral). ${ }^{63}$ For each of the five subscales, scores can vary from 0 to 10; total difficulties scores are generated by the sum of the results obtained in all subscales - except for prosocial behavior, whose score can vary from 0 to 40 . The cut-off score adopted for the total difficulties score was 17 for the parents' version and 16 for the teachers' version. Higher scores indicate more occurrences of mental health problems, and the instrument classifies children's and adolescents' symptoms as normal, borderline or abnormal. ${ }^{63,64}$ For this study, the borderline classification was considered clinical.

The SDQ is available in over 40 languages, including Portuguese. ${ }^{64,65}$ It has been translated and validated in Brazil with adequate psychometric properties for the Brazilian population. ${ }^{64}$ In this study, the self-report version presented with an $a=0.78$.

\section{Data collection procedure}

Data collection comprised the following steps: a) contacting the school; b) inviting adolescents and handing out the parental written informed consent form, which the parents had to sign in order to participate in the study; c) applying the tests during a class period; d) giving the results back to the educational institution and to the adolescents. We contacted the parents or guardians of the adolescents who showed borderline or clinical classifications on the SDQ.

\section{Ethical procedure}

This study was conducted in accordance with Resolution 466/12 of the Brazilian National Health Council ${ }^{66}$ and was referred to and approved by the ethics committee of UNISINOS. All participants had parental permission to participate in the study and were informed about the purpose of the research via an explanatory document. The anonymity of the participants was ensured, as were any requests to withdraw from the study at any time during the study.

\section{Data analysis procedures}

Analyses were performed using the Statistical Package for the Social Sciences (SPSS). Significance was set at $5 \%(p \leq 0.05)$. Statistical tests performed in this study were parametric tests, comprising descriptive and inferential analysis.

\section{Results}

The descriptive analysis indicated that 57 (30.3\%) adolescents had clinical symptoms, whereas 131 (69.9\%) did not have symptoms, comprising the nonclinical group. The total sample had a mean age of 15.83 years (standard deviation $[S D]=0.76$ ). Twenty-five percent of the adolescents had failed at least one year at school.

In the investigated group, girls showed higher scores of internalizing symptoms than boys $(M=16.62$, $\mathrm{SD}=3.62 ; t=2.62 ; \mathrm{p} \leq 0.05)$ as well as externalizing symptoms $(M=16.72, \mathrm{SD}=3.63 ; t=2.74 ; \mathrm{p} \leq 0.01)$. Also, girls had a lower level of reflective function ( $M$ $=8.34, \mathrm{SD}=0.83 ; t=-2.26 ; \mathrm{p} \leq 0.05$ ) and a higher disintegration of identity: discontinuity of total identity $(M=44.16, S D=18.43 ; t=3.02 ; p \leq 0.05)$ and incoherence of total identity $(M=44.63, S D=23.61 ; t$ = 2.63; $\mathrm{p} \leq 0,01$ ) (Table 3).

The correlation between the scores of RFQY and SDQ, as seen in Table 4, showed a negative association between reflective function and the presence of symptoms, indicating that adolescents with a higher incidence of mental health problems showed lower reflective function. In general, the presence of both internalizing symptoms $(r=-0.242, p<0.01)$ and externalizing symptom $(r=-0.198, \mathrm{p}<0.01)$ showed weak negative correlations with reflective function.

Regarding identity, the comparison between the groups in terms of total mean scores obtained in Scale 1 (continuity vs. discontinuity) indicated that adolescents with clinical symptoms had higher scores of total identity discontinuity $\left(M=65.08 ; S D=15.85 ; F_{1,47}=65.08 ; p=\right.$ $0.0)$, i.e., they represented themselves as unstable and discontinuous over time. Considering the overall means obtained in Scale 2 (consistency vs. inconsistency), adolescents with clinical symptoms showed incoherence of identity, indicating fragmentation of self and lack of autonomy $\left(F_{1,47}=59.74 ; p=0.0\right)$. Table 5 shows the data corresponding to the two overall scales: continuity vs. discontinuity and consistency vs. inconsistency.

Pearson correlations between RFQY and AIDA scores indicated that reflective function is inversely related to identity discontinuity $(r=-0.342, p<0.01)$. It is also associated with identity incoherence $(r=-0.414$, $\mathrm{p}<0.01$ ).

Through logistic regression analysis, with regard to the classification of SDQ in relation to sociodemographic variables, we found that only gender was associated with a clinical classification on the SDQ: females had twice as many cases classified as clinical as males (Table 6).

\section{Discussion}

Adolescents need to integrate various aspects of their identities: reorganize their personal awareness, control 
sexual impulses, regulate emotional intensity, manage abstraction and symbolization, meet standards and expectations, overcome separation, establish intimacy in relationships and achieve greater autonomy. ${ }^{67}$ The development of reflective function has been considered a protective factor, as it assists in the assimilation of losses and the transformations characteristic of adolescence, keeping the individual safe and stable. ${ }^{18,31,49}$

According to Barkai \& Rappaport, more resilient adolescents have improved reflective function when compared to those who experience psychopathology. ${ }^{68}$ Deficits in reflective function were associated with adolescents who are diagnosed as borderline, ${ }^{64,69}$ depressive, ${ }^{70}$ psychopathic, ${ }^{11}$ and anxious, ${ }^{12}$ among others. In this study, we found that difficulties in reflective function were significantly correlated with the occurrence of symptoms in adolescents, both internalizing and externalizing.

With regard to identity, a personal sense of discontinuity and incoherence was observed in the adolescents who showed clinical symptoms in the present sample. In this case, the subjective experience of self was unstable over time, fragmented, with no perspective or future plans. Moreover, these experiences

Table 3 - Scores obtained by female and male adolescents on SDQ, AIDA, and RFQY

\begin{tabular}{|c|c|c|c|c|c|c|}
\hline & \multicolumn{2}{|c|}{ Female } & \multicolumn{2}{|c|}{ Male } & \multirow[b]{2}{*}{$t$} & \multirow[b]{2}{*}{$\mathbf{p}$} \\
\hline & M & SD & M & SD & & \\
\hline \multicolumn{7}{|l|}{ SDQ } \\
\hline Externalizing symptoms & 16.86 & 3.65 & 15.22 & 3.09 & 3.20 & $0.002 *$ \\
\hline Conduct problems & 1.31 & 0.46 & 1.12 & 0.33 & 2.89 & $0.004 *$ \\
\hline Hyperactivity/inattention & 1.20 & 0.40 & 1.20 & 0.40 & 0.10 & 0.917 \\
\hline Internalizing symptoms & 16.68 & 3.61 & 15.27 & 3.16 & 2.70 & $0.010^{+}$ \\
\hline Emotional symptoms & 1.33 & 0.47 & 1.12 & 0.33 & 3.21 & $0.002 *$ \\
\hline Relationship problems & 1.26 & 0.44 & 1.28 & 0.45 & -0.22 & 0.826 \\
\hline Prosocial behavior & 1.16 & 0.36 & 1.12 & 0.33 & 0.68 & 0.49 \\
\hline \multicolumn{7}{|l|}{ AIDA } \\
\hline Continuity total & 57.97 & 15.19 & 52.88 & 11.01 & 2.19 & $0.030^{+}$ \\
\hline Continuity sub 1 & 16.65 & 5.93 & 14.63 & 5.23 & 2.33 & $0.021^{+}$ \\
\hline Continuity sub 2 & 16.38 & 9.10 & 14.06 & 5.77 & 1.76 & 0.080 \\
\hline Continuity sub 3 & 11.10 & 7.96 & 8.39 & 4.72 & 2.45 & $0.015^{+}$ \\
\hline Coherence total & 44.75 & 24.08 & 37.13 & 19.00 & 2.00 & $0.047^{+}$ \\
\hline Coherence sub 1 & 16.58 & 10.82 & 14.35 & 8.85 & 1.34 & 0.18 \\
\hline Coherence sub 2 & 16.47 & 8.36 & 13.67 & 6.29 & 2.26 & $0.025^{+}$ \\
\hline Coherence sub 3 & 11.64 & 6.69 & 8.70 & 5.88 & 3.04 & $0.003^{+}$ \\
\hline \multicolumn{7}{|l|}{ RFQY } \\
\hline Reflective function & 4.19 & 0.39 & 4.34 & 0.38 & -2.20 & $0.030^{+}$ \\
\hline
\end{tabular}

AIDA = Assessment of Identity Development in Adolescence; $M=$ mean; RFQY = Reflective Function Questionnaire for Youths; SD = standard deviation; SDQ $=$ Strengths and Difficulties Questionnaire.

$* \mathrm{p} \leq 0.01 ;{ }^{+} \mathrm{p} \leq 0.05$.

Table 4 - Pearson correlations between RFQ and SDQ subscales and total scores

\begin{tabular}{|c|c|c|c|c|c|}
\hline & RFQY total & SDQ total & $\begin{array}{l}\text { Prosocial } \\
\text { behavior }\end{array}$ & $\begin{array}{c}\text { Internalizing } \\
\text { symptoms }\end{array}$ & $\begin{array}{c}\text { Externalizing } \\
\text { symptoms }\end{array}$ \\
\hline RFQY total score & 1 & & & & \\
\hline SDQ total score & $-0.184^{*}$ & 1 & & & \\
\hline Prosocial behavior & $0.228^{+}$ & 0.130 & 1 & & \\
\hline Internalizing symptoms & $-0.181^{*}$ & $0.684^{+}$ & 0.131 & 1 & \\
\hline Externalizing symptoms & $-0.184 *$ & $0.674^{+}$ & $0.178 *$ & $0.454^{+}$ & 1 \\
\hline
\end{tabular}

RFQY = Reflective Function Questionnaire for Youths; SDQ = Strengths and Difficulties Questionnaire.

${ }^{*} \mathrm{p} \leq 0.05 ;{ }^{+} \mathrm{p} \leq 0.01$. 
of self and the other indicated difficulties following rules, instability in relationships, misunderstanding of self and others when it came to emotions, and behaviors reflecting incoherence of self. According to Clarkin et al., diffusion of identity is characterized by difficulty engaging in occupation, family, and social interactions, to comply with common social standards, and to evaluate their own emotional states and confusion about themselves. ${ }^{56}$

The present data are similar to those of other studies that indicate that identity is a result of a representational model of self and object representations (i.e., the other), with the development of emotional regulation and reflective function.7,49 Thus, individuals with a more disintegrated identity tend to have less ability to mentalize and trust others and to have a higher level of anxiety, which ends up causing psychopathological manifestations. ${ }^{71}$

Correlating the two variables (reflective function and identity), we observed that reflective function is inversely associated with discontinuity and incoherence of identity. This finding reinforces that reflective function elements are intrinsic to identity, so that poor development of reflective function interferes significantly in integrating the subject's identity. It appears that, in many ways, the present data, mainly the scores obtained on subscale 3 (emotional and cognitive self-reflection), approach the reflective function concept. Fonagy et al. showed that the ability to recognize internal states as well as those of others is a prerequisite of the development of identity. ${ }^{49}$

Relations between drug addiction and mental health have been well established: adolescents who have a secure attachment are more open, independent, socially accepted, and have a lower level of psychopathology. Conversely, those with insecure attachments have higher levels of depression, anxiety, relationship difficulties, and increased risk of psychopathology. ${ }^{72}$ The literature suggests that insecure attachment is associated with low levels of reflective function/mentalization. 6,45,69,73-75

It is noteworthy that the only relevant sociodemographic variable associated with clinical symptoms was gender, indicating that girls demonstrated greater difficulties in adolescent transformation. In this study, the girls had lower levels of reflective function as well as more frequent occurrence of mental health problems, with both internalizing and externalizing symptoms. Furthermore, there was a significant difference between the genders with regard to the integration of identity on both the consistency and the continuity scales, with girls presenting higher scores.

The literature suggests that internalizing problems are more common in females, whereas externalizing

Table 5 - Mean continuity/discontinuity and coherence/incoherence of identity scores obtained with the SDQ subscales

\begin{tabular}{|c|c|c|c|c|c|c|c|c|c|c|c|c|}
\hline & \multicolumn{6}{|c|}{ Continuity/discontinuity total } & \multicolumn{6}{|c|}{ Coherence/incoherence total } \\
\hline & \multicolumn{3}{|c|}{ Clinical } & \multicolumn{3}{|c|}{ Nonclinical } & \multicolumn{3}{|c|}{ Clinical } & \multicolumn{3}{|c|}{ Nonclinical } \\
\hline & $\mathbf{M}$ & SD & $\mathbf{n}$ & M & SD & $\mathbf{n}$ & M & SD & $\mathbf{n}$ & M & SD & $\mathbf{n}$ \\
\hline Total SDQ & $65.08^{*}$ & 15.85 & 47 & $52.85 *$ & 11.78 & 119 & $59.74 *$ & 23.17 & 47 & $34.67 *$ & 17.96 & 110 \\
\hline Emotional symptoms & $65.40 *$ & 15.15 & 45 & $52.94 *$ & 12.18 & 121 & $61.46 *$ & 21.84 & 39 & $35.80 *$ & 19.20 & 118 \\
\hline Conduct problems & $61.26^{+}$ & 13.31 & 41 & $54.69^{+}$ & 14.07 & 125 & $51.63^{+}$ & 22.21 & 41 & $38.83^{+}$ & 22.04 & 116 \\
\hline Hyperactivity/inattention & $63.06^{+}$ & 11.26 & 33 & $54.64^{+}$ & 14.31 & 133 & $58.21 *$ & 23.18 & 33 & $37.91 *$ & 20.68 & 124 \\
\hline Relationship problems & 64.34* & 16.46 & 43 & $53.51 *$ & 12.10 & 123 & $54.90 *$ & 19.97 & 43 & $37.37 *$ & 21.90 & 114 \\
\hline Prosocial behavior & $62.75^{ \pm}$ & 11.29 & 24 & $55.23^{\ddagger}$ & 14.31 & 142 & $50.80^{\ddagger}$ & 25.98 & 26 & $40.46^{ \pm}$ & 21.72 & 131 \\
\hline
\end{tabular}

$\mathrm{M}=$ mean; $\mathrm{n}=$ number of participants; $\mathrm{SD}=$ standard deviation; $\mathrm{SDQ}=$ Strengths and Difficulties Questionnaire.

* $\mathrm{p}=0 ;{ }^{+} \mathrm{p} \leq 0.01 ;{ }^{*} \mathrm{p} \leq 0.05$.

Table 6 - Logistic regression: cross-tabulation $(n=188)$

\begin{tabular}{lccc}
\hline Sex & Nonclinical & Clinical & Total \\
\hline Females & 79 & 45 & 124 \\
Mean score & $63.7 \%$ & $36.3 \%$ & $100.0 \%$ \\
$\%$ in sex & & & \\
Males & 52 & 12 & 64 \\
Mean score & $81.2 \%$ & $18.8 \%$ & $100.0 \%$ \\
\% in sex & & & \\
\hline
\end{tabular}


problems are more common in males. ${ }^{76,77}$ For example, a study with 320 adolescents found that girls had a higher percentage of anxiety disorders and depression, while the boys showed a higher percentage of social problems. ${ }^{78}$ However, other studies showed no significant differences between boys and girls as to internalizing and externalizing problems. ${ }^{77}$ According to Merikangas et al., the total score of behavior problems as well as of externalizing problems diminishes with age, while on the other hand, internalizing scores increase. ${ }^{79}$

The presence of mental health problems in adolescence highlights the need for the development of prevention and intervention actions. Such actions targeted at the mental health of young people could play an important role in preventing the establishment of disorders in adulthood.

\section{Conclusion}

The investigation of reflective function and identity is a complex procedure, especially in adolescence. So far, few Brazilian studies have investigated reflective function/mentalizing, and none has focused on the association between reflective function and the development of identity. Thus, we stress the importance of continuous research studies on reflective function and identity.

The present data provide a scientific contribution that is relevant to the clinical context, thus approximating research and practice. The results can aid in better understanding adolescents and suggests an urgent need for more appropriate interventions for these individuals, focusing on reflective function level and identity integration. This finding points to the possibility of interventions that might lead to therapeutic change, with therapy that focuses on the development of reflective function, for example.

It should be noted that this study has some limitations with regard to the participants, which were specific to the Serra Gaúcha context at the school investigated. There was little difference in age, and the sample was too small to form subgroups for each subscale of the SDQ. Also, diagnostic classification was limited to categorization by only one evaluation instrument. Another limitation refers to the absence of different cutoffs according to gender, which may have led to erroneous conclusions. Thus, it is suggested that this research be continued in different contexts and with more representative samples to build more consistent knowledge.

\section{Disclosure}

No conflicts of interest declared concerning the publication of this article.

\section{References}

1. Teodoro MLM, Hess ARB, Saraiva LA, Cardoso BM. Problemas emocionais e de comportamento e clima familiar em adolescente e seus pais. Psico. 2014;45:168-75.

2. Thiengo DL, Cavalcante MT, Lovisi GM. Prevalência de transtornos mentais entre crianças e adolescentes e fatores associados: uma revisão sistemática. J Bras Psiquiatr. 2014;63:360-72.

3. Paula CS, Duarte CS, Bordin IA. Prevalence of mental health problems in children and adolescents from the outskirts of Sao Paulo City: treatment needs and service capacity evaluation. Rev Bras Psiquiatr. 2007;29:11-7.

4. Patel V, Flisher AJ, Hetricks S, McGorry P. Mental health of young people: a global public health challenge. Lancet. 2007;369:130213.

5. Merikangas KR, He JP, Brody D, Fisher PW, Bourdon K, Koretz DS. Prevalence and treatment of mental disorders among US children in the 2001-2004 NHAES. Pediatrics. 2010;125:75-81.

6. Fonagy $\mathrm{P}$, Bateman AW. Adversity, attachment, and mentalizing. Compr Psychiatry. 2016;64:59-66.

7. Kernberg PF, Weiner AS, Bardenstein KK. Transtorno de personalidade em crianças e adolescentes: uma visão geral. Porto Alegre: Artmed; 2003.

8. Fischer-Kern M, Tmej A, Kapusta ND, Naderer A, LeithnerDziubas K, Löffler-Stastka $\mathrm{H}$, et al. The capacity for mentalization in depressive patients: a pilot study. Psychosom Med Psychother. 2008; 54:368-80.

9. Brent BK. A mentalization-based approach to the development of the therapeutic aliance in the treatment of schizophrenia. J Clin Psychol. 2015;71:146-56.

10. Sharp C. Mentalizing problems in childhood disorders. In: Allen J, Fonagy $\mathrm{P}$, editors. Handbook of mentalization-based treatment. Chichester: John Wiley \& Sons; 2006. p. 101-21.

11. Taubner S, White LO, Zimmermann J, Fonagy $P$, Nolte T. Attachment-related mentalization moderates the relationship between psychopathic traits and proactive aggression in adolescence. J Abnorm Child Psychol. 2013;41:929-38.

12. Nolte $T$, Guiney J, Fonagy $P$, Mayes LC, Luyten P. Interpersonal stress regulation and the development of anxiety disorders: an attachment-based development framework. Front Behav Neurosci. 2011;5:55.

13. D'Onofrio $E$, Pace CS, Cavanna $D$. Qualitative research in adolescent psychotherapy: attachment and reflective functioning as psychotherapy's outcomes of adolescent with anorexia nervosa. Res Psychother Psychopathol Process Outcome. 2015;18:93101.

14. Bateman A, Fonagy P. Mentalization-based treatment for borderline personality disorder: a practical guide. Oxford: Oxford University Press; 2006.

15. Fonagy $\mathrm{P}$, Target $\mathrm{M}$. Attachment and reflective function. Dev Psychopathol. 1997;9:679-700.

16. Ammaniti M, Fontana A, Clarkin A, Clarkin JF, Nicolais G, Kernberg OF. Assessment of adolescent personality disorders through the interview of personality organization processes in adolescence (IPOP-A): clinical and Theoretical Implications. Adolesc Psychiatr. $2012 ; 2: 36-45$

17. Zimerman D. (1999). Fundamentos psicanalíticos: teoria, técnica e clínica - uma abordagem didática. Porto Alegre: Artmed; 2010.

18. Ensink K, Fonagy $\mathrm{P}$, Normandin L, Berthelot N, Biberdzic M, Duval J. O papel protetor da mentalização de experiências traumáticas: implicações quando da entrada na parentalidade. Estilos Clin. 2015;20:76-91.

19. Feitosa HN, Ricou M, Rego M, Nunes R. A saúde mental das crianças e dos adolescentes: considerações epidemiológicas, assistenciais e bioéticas. Rev Bioetica. 2011;19:259-75.

20. Sharp C, Ha C, Michonski J, Venta A, Carbone C. Borderline personality disorder in adolescents: evidence in support of the Childhood Interview for DSM-IV Borderline Personality 
Disorder in a sample of adolescent inpatients. Compr Psychiatry. 2012;53:765-74.

21. Skodol AE. Assessing personality disorder in adolescents from the perspective of DSM-5. Clin Psychol Sci Pract. 2014;21:84-90.

22. Jordão $A B$. Vínculos familiares na adolescência: nuances e vicissitudes na clínica psicanalítica com adolescentes. Aletheia. 2008;21:157-72.

23. Amparo DM, Brasil KTR, Wolff LS. Adolescência e psicose: traumatismo e violência do pubertário. Interam J Psychol. 2010;44:507-14.

24. Bassols AMS, Kapczinski F, Eizirik CL. O ciclo da vida humana: uma perspectiva psicodinâmica. Porto Alegre: Artmed; 2001.

25. Massa JLP, Rubio VB, Pérez-Chacón MM, Quirós S. Psicopatología en la adolescencia. Medicine. 2014;11:3612-21.

26. Seron C, Milani RG. A construção da identidade feminina na adolescência: um enfoque na relação mãe e filha. Psicol Teor Prat. 2011;13:154-64.

27. Biazus CB. A psicoterapia baseada na mentalização para o tratamento da depressão na adolescência [dissertação] São Leopoldo: Universidade do Vale do Rio dos Sinos; 2011.

28. Levisky DL. Depressões narcísicas na adolescência e o impacto da cultura. Psyche. 2002;6:125-36.

29. Levy R. Adolescencia: el reordenamiento simbólico, el mirar y el equilibrio narcisístico. Psicoanalisis. 207;29:363-75.

30. Bowlby J. (1973). Apego e perda. São Paulo: Martins Fontes; 1998. Vol. 2. Separação: angústia e raiva.

31. Fonagy P. Persistencias transgeneracionales del apego: una nueva teoría. Apert Psicanal. 1999;3.

32. Pinto A, Gatinho A, Silva F, Veríssimo M, Santos A. Vinculação e modelo interno dinâmico do self em crianças de idade pré-escolar. Psicol Saude Doenca. 2013;14:515-28.

33. Bowlby J. (1969). Apego e perda. Apego. São Paulo: Martins Fontes; 2002.

34. Riani A, Caropreso F. O desenvolvimento psíquico precoce e o risco de psicose de uma perspectiva psicanalítica. Mental. 2013;19:249-65.

35. Santos NTG, Zornig AS. Primeiros tempos da maternidade: indiferenciação ou intersubjetividade na relação primitiva com o bebê? Estilos Clin. 2014;19:78-90.

36. Blatt SJ, Auerbach JS, Levy KN. Mental representations in personality development, psychopathology, and the therapeutic process. Rev Gen Psychol. 1997;1:351-74.

37. Zanatta D, Benetti SPC. Representação mental e mudança terapêutica: uma contribuição da perspectiva psicanalítica da teoria das relações objetais. Psic Teor Pesq. 2012;28:93-100.

38. Priel B, Besser A, Waniel A, Yonas-Segal M, Kupermic G. Interpersonal and intrapersonal processes in the formationof maternal representations in middle childhood: review, new findings and future directions. Isr J Psychiatry Relat Sci. 2007; 44:255-65.

39. Custódio S, Cruz O. As representações mentais das crianças acerca das figuras parentais. Psic Teor Pesq. 2008;24:393-405.

40. Bateman A, Fonagy P. Tratamento baseado na mentalização e transtorno de personalidade borderline. In: Clarkin JF, Fonagy P, Gabbard GO, organizadores. Psicoterapia psicodinâmica para transtornos de personalidade: um manual clínico. Porto Alegre: Artmed; 2013

41. Allen JP, Fonagy P. The handbook of mentalization based treatment. Chichester: John Wiley \& Sons; 2006.

42. Bateman A, Fonagy P. Psychotherapy of borderline personality disorder: mentalization-based treatment. Oxford: Oxford University; 2004.

43. Fonagy P, Bateman AW. The development of an attachmentbased treatment program for borderline personality disorder. Bull Menninger Clin. 2003;67:187-211.

44. Fonagy $\mathrm{P}$, Bateman AW. Mentalizing and borderline personality disorder. J Ment Health. 2007;16:83-101.

45. Bateman A, Fonagy P. Mentalization based treatment for borderline personality disorder. World Psychiatry. 2010;9:11-5.

46. Fonagy $P$, Allison $E$. What is mentalization? The concept and its foundation in developmental research. In: Midgley $\mathrm{N}$, Vrouva I. Minding the child. London: Routledge; 2012. p. 11-34.

47. Sharp C, Williams LL, Ha C, Baumgardner J, Michonski J, Seals $\mathrm{R}$, et al. The development of a mentalization-based outcomes and research protocol for an adolescent in-patient unit. Bull Menninger Clin. 2009;73:311-38.

48. Weinberg E. Mentalization, affect regulation, and development of the self. Panel Report. J Am Psychoanal Assoc. 2006;54:251-70.
49. Fonagy P, Gergely G, Jurist EL, Schafer WD. Affect regulation, mentalization, and the development of the self. New York: Other; 2002.

50. Fonagy $P$, Target $M$. Questões desenvolvimentais na adolescência normal e colapso na adolescência. In: Graña RB, Piva ABS. A atualidade da psicanálise de adolescentes - formas do mal-estar na juventude contemporânea. São Paulo: Casa do Psicólogo; 2004. p. 91-106.

51. American Psychiatric Association. Diagnostic and Statistical Manual of Mental Disorders, Fifth Edition (DSM-5). Arlington: American Psychiatric Publishing; 2013.

52. Erikson EH. Identidade, juventude e crise. Rio de Janeiro: Guanabara; 1968.

53. Kassin M, Castro F, Arango I, Goth K. Psychometric propries of a culture-adapted Spanish version of AIDA (Assessment of Identity Development in Adolescence) in Mexico. Child Adolesc Psychiatry Ment Health. 2013;7:25.

54. Westen D, Betan E, Defife JA. Identity disturbance in adolescence: associations with borderline personality disorder. Dev Psychopathol. 2011;23:305-13.

55. Kernberg OF, Selzer MA, Koenigsberg HW, Carr AC, Appelbaum $\mathrm{AH}$. Psicoterapia psicodinâmica de pacientes borderline. Porto Alegre. Artes Médicas; 1991.

56. Clarkin JF, Yeomans FE, Kernberg OF. Psychoterapy of borderline personality: focusing on object relations. Washington: APA; 2006.

57. Feenstra DJ, Hutsebaut J, Verheul R, Limbeek JV. Changes in the identity integration of adolescents in treatment for personality disorders. J Pers Dis. 2014;28:101-12.

58. Grossi R, Moura CB, Sampaio ACP, Silva LC. Questionário de situações domésticas: comparação entre pré-escolares clínicos e não-clínicos. Psic Teor Pesq. 2010;26:57-66.

59. Valverde BSCL, Vitalle MSS, Sampaio IPC, Shoen, TH. Levantamento de problemas comportamentais/emocionais em um ambulatório para adolescentes. Paideia. 2012;22:315-23.

60. Brasil. Censo demográfico 2000: características gerais da população. Resultados da amostra [Internet]. 2010. [cited 2018 Dec 01]. https://ww2.ibge.gov.br/home/estatistica/populacao/ censo2000/default_populacao.shtm

61. Goth $K$, Foelsch $P$, Schlüter-Müller $S$, Birkhölzer $M$, Jung $E$, Pick $O$, et al. Assessment of identity development and identity diffusion in adolescence - theoretical basis and psychometric properties of the self-report questionnaire AIDA. Child Adolesc Psychiatry Ment Health. 2012;19:6-27.

62. Ha C, Sharp C, Ensink K, Fonagy P, Cirino PP. The measurement of reflective function in adolescents with and without borderline traits. J Adolesc. 2013;36:1215-23.

63. Goodman R. The Strengths and Difficulties Questionnaire: a research note. J Child Psychol Psychiatr. 1997;38:581-6.

64. Fleitlich BW, Cortazar PG, Goodman R. Questionário de Capacidades e Dificuldades (SDQ). Infanto. 2000;8:44-50.

65. Saur AM, Loureiro SR. Qualidades psicométricas do Questionário de Capacidades e Dificuldades: revisão de literatura. Estud Psicol. 2012;29:619-29.

66. Brasil, Ministério da Saúde, Conselho Nacional de Saúde. Resolução no 466, de 12 de dezembro de 2012 [Internet]. [cited 2018 Dec 01]. http://bvsms.saude.gov.br/bvs/saudelegis/ cns/2013/res0466_12_12_2012.html

67. Bleiberg E. La terapia basada en la mentalización para adolescentes y famílias. Rev Mentalizacion. 2015;2:2.

68. Barkai AR, Rappaport N. A psychiatric perspective on narratives of self-reflection in resilient adolescents. Adolesc Psyciatr. 2011;1:46-54.

69. Sharp C, Venta A, Vanwoerden S, Schramm A, Ha C, Newlin E, et al. First empirical evaluation of the link between attachment, social cognition and borderline features in adolescents. Compr Psychiatry. 2016;64:4-11.

70. Biazus CB, Ramires VRR. Depressão na adolescência: uma problemática dos vínculos. Psicol Estud. 2012;17:83-91.

71. Carriço CN, Paixão R. Vinculação, memórias de infância e estilos defensivos na população dependente de substâncias: estudo comparativo e multivariado. Psychologica. 2010;52:2.

72. Allen JP, Porter M, McFarland C, McElhaney KB, Marsh P. The relation of attachment security to adolescent's paternal and peer relationships, depression, and externalizing behavior. Child Dev. 2007;78:1222-39.

73. Fossati A, Feeney J, Maffei C, Borroni S. Thinking about feelings: affective state mentalization, attachment styles, and 
borderline personality disorder features among italian nonclinical adolescents. Psychoanal Psychol. 2014;31:41-67.

74. Jewell $\mathrm{T}$, Collyer $\mathrm{H}$, Gardner $\mathrm{T}$, Tchanturia K, Simic M, Fonagy $\mathrm{P}$, et al. Attachment and mentalization and their association with child and adolescent eating pathology: a systematic review. Int J Eat Disord. 2016;49:354-73.

75. Sharp C, Vanwoerden S. Hypermentalizing in borderline personality disorder: a model and data. J Infant Child Adolesc Psychother. 2015;14:33-45.

76. Fleitlich-Bilyk B, Goodman R. Prevalence of child and adolescent psychiatric disorders in southeast Brazil. J Am Acad Child Adolesc Psychiatry. 2004;43:727-34.

77. Sourander A, Niemela S, Santalahti I, Helenius H, Piha J. Changes in psychiatric problems and service use among 8-year-old children: a 16 year population-based time-trend study. J Am Acad Child Adolesc Psychiatry. 2008;47:317-27.
78. Borsa JC, Souza DS, Bandeira DR. Prevalência dos problemas de comportamento em uma amostra de crianças do Rio Grande do Sul. Psicol Teor Prat. 2011;13:15-29.

79. Merikangas KR, He J, Burstein M, Swanson SA, Avenevoli S, Cui L, et al. Lifetime prevalence of mental disorders in U.S. adolescents: results from the National Comorbidity Survey Replication-Adolescent Supplement (NCS-A). J Am Acad Child Adolesc Psychiatry. 2010;49:980-9.

\section{Correspondence:}

Luciane Maria Both

Av. Unisinos, 1505, apto 102-A

93022-750 - São Leopoldo, RS - Brazil

Tel.: +55 (54) 996145522

E-mail: lucianeboth@gmail.com 